This PDF is a selection from a published volume from the National Bureau of Economic Research

Volume Title: Social Security Programs and Retirement around the World: The Relationship to Youth Employment

Volume Author/Editor: Jonathan Gruber and David A. Wise, editors

Volume Publisher: University of Chicago Press

Volume ISBN: 978-0-226-30948-4; 0-226-30948-7

Volume URL: http://www.nber.org/books/grub08-1

Conference Date:

Publication Date: February 2010

Chapter Title: Do Elderly Workers Substitute for Younger Workers in the United States?

Chapter Author: Jonathan Gruber, Kevin Milligan

Chapter URL: http://www.nber.org/chapters/c8262

Chapter pages in book: (345 - 360) 


\title{
Do Elderly Workers Substitute for Younger Workers in the United States?
}

\author{
Jonathan Gruber and Kevin Milligan
}

The Social Security program has been the single biggest social insurance program in the United States for decades. It is viewed as a vital piece of the nation's safety net, providing security and well-being for the elderly. Yet it is also a program with a long-run fiscal shortfall that soon will be spending more than it collects and that by roughly 2050 will have no savings left from the existing trust funds to finance that benefit shortfall. As a result, there is a wide ranging policy discussion over reform to the program. Suggestions range from the straightforward (raising the payroll tax that finances the program) to the more exotic (private savings accounts to replace the existing system).

A number of the policy options considered would impact the labor force decisions of the elderly, as discussed in Coile and Gruber (2004, 2007). For example, Coile and Gruber (2004) estimate that raising both the early and normal retirement age by three years would lead to significantly lower retirement rates, with the odds of participating in the labor force at age sixty-five rising by as much as 20 percentage points.

One question that is often raised in international discussion is whether such an increase in the labor supply of the elderly will lead to a reduction in the labor supply of young and prime age workers. A common view expressed in the international context is the "lump of labor" view that there are a fixed

Jonathan Gruber is professor of economics at the Massachusetts Institute of Technology and director of the Program on Health Care at the National Bureau of Economic Research, where he is a research associate. Kevin Milligan is associate professor of economics at the University of British Columbia, and a faculty research fellow of the National Bureau of Economic Research.

This paper was prepared as part of the National Bureau of Economic Research's (NBER) International Social Security project, organized by Jonathan Gruber and David A. Wise. We thank Natalija Novta for research assistance with the incentive calculator. 
number of jobs, so that if more of those jobs are taken by the nonretiring elderly, there will be fewer such jobs for the young. This view is commonly disputed by economists, however, who argue that the labor market is not a fixed box but is rather a dynamic market that can adapt to large changes in labor supply. In the U.S. context, this view appears to dominate, as there has been little discussion of the "crowding out" of the young by older workers.

In this paper, we investigate the extent of such "crowding out" in the United States over time. We begin by documenting time series trends in labor supply by age group. We then turn to a more formal regression analysis of those trends. Finally, we develop a measure of the variation over time in the incentives for retirement of the elderly and relate that to the labor supply of both the elderly and younger workers. Overall, our data suggest little substitution across these groups.

\subsection{Background}

\subsubsection{Institutional Features of Social Security}

As this paper focuses on labor supply responses to Social Security reform, a brief overview of the Social Security program is necessary to understand how the program affects retirement; see Diamond and Gruber (1998) for a more detailed review. An individual is entitled to retired worker benefits once he or she has worked forty quarters in covered employment. Benefits are calculated in several steps. Annual earnings are indexed by an average wage index, and the thirty-five highest years of earnings are used to compute the average indexed monthly earnings (AIME) ${ }^{1}$ A progressive formula is applied to the AIME to obtain the primary insurance amount (PIA). Finally, the PIA is adjusted to obtain the monthly benefit amount based on when benefits are first received. Individuals claiming at the normal retirement age (NRA, legislated to grow slowly from sixty-five to sixty-seven) receive the PIA. Individuals can receive benefits as early as age sixty-two (the early retirement age, or ERA) or can delay until age seventy. Benefits are reduced by 6.67 percent for each year of receipt prior to the NRA and are increased by a delayed retirement credit of 3 percent to 8 percent for each year receipt is postponed past the NRA, depending on the worker's birth year. ${ }^{2}$ Benefit receipt is subject to an earnings test before age sixty-five, whereby earnings above a floor amount reduce benefits currently and cause them instead to be paid out (with an actuarial adjustment) upon full retirement. Spouses of beneficiaries also receive a dependent benefit equal to 50 percent of the

1. Earnings after age sixty are in nominal dollars, increasing the incentive to work at these ages.

2. The delayed retirement credit (DRC) is rising from 3 percent for workers born prior to 1925 to 8 percent for workers born after 1942. For workers with an NRA above sixty-five, benefits are reduced 5 percent per year for receipt more than three years before the NRA. 
worker's PIA or a survivor benefit equal to 100 percent of the worker's PIA although the spouse receives only the larger of this and his or her own retired worker benefit. Benefits are funded with a payroll tax of 12.4 percent, paid half by employers and half by employees.

Additional work affects Social Security wealth in several ways. First, the additional year of earnings may replace an earlier year of zero or low earnings in the AIME calculation, raising the monthly benefit. Second, work beyond age sixty-two implies a delay in claiming benefits (if earnings are significantly above the earnings test floor). Benefits are foregone for a year, but future benefits are higher due to the actuarial adjustment. Finally, additional work results in additional payroll taxes. The combination of these three effects determines whether the Social Security system provides a return to additional work that is more or less than actuarially fair.

\subsubsection{Concerns over "Crowding Out" of Labor Supply of Young}

The United States has really had only two major reforms of its Social Security system over the past thirty years. The first was the "Greenspan Commission" in 1983, called in to solve an impending fiscal crisis for the program. Part of the Commission's recommendations, which were adopted into law, was extending the "normal retirement age" from age sixty-five to age sixty-seven over a period of many years. As Coile and Gruber (2007) estimate, such a reform has a relatively modest impact on retirement decisions because the actuarially fair U.S. system makes incentives roughly neutral around retirement ages. Perhaps as a result, there is no evidence of a significant discussion about the labor market consequences of this bill for the nonelderly. A detailed literature search found only one article from this entire era addressing the issue. Hicks $(1977,33)$ writes "Increasing the retirement age may cost the unemployed as many as 150,000 to 200,000 jobs a year, plus delaying the promotions of those already working."

The second major reform was the removal of the "earnings test" for Social Security after age sixty-five, which was legislated in 2000. Once again there was little discussion of possible substitution of the labor supply of the elderly for that of the young. Smith (2003) titled her article "Senior Citizens Are among Teenagers' Job Competition," but the article itself contains little discussion of this point. Congressman Jim Bunning, in announcing a hearing on the future of Social Security, did say about options to raise the retirement age, "But retirement income might be lower for those who cannot work longer due to employers continuing to provide incentives for older workers to retire and make room for younger workers" (Committee on Ways and Means 1998).

This is only a very modest set of comments on an issue that is a major source of discussion in other nations. Somehow, the "lump of labor" view does not appear to have taken hold in a meaningful way in the United States. 


\subsection{Time Series Trends}

Our analysis of the labor market impacts of changing elderly labor force participation uses data from the nation's largest annual labor market survey, the Current Population Survey (CPS). We use data from the annual March supplement to the CPS, for most years from 1962 through 2007. ${ }^{3}$ This supplement includes detailed questions about labor force participation that are fairly constant over time. We divide our sample into three age groups: those twenty to twenty-four (the "young"), those twenty-five to fifty-four ("prime age"), and those fifty-five to sixty-four (the "elderly"). We examine several variables of interest: labor force participation (LFP), employment, and unemployment. We take averages of these measures for each age group over time using the provided survey weights. The analysis is presented in each case first for both sexes pooled together, then for males and females separately.

Time series comparisons of the trends across age groups are shown in panel A of figure 12.1. The labor force participation (LFP) of the elderly displays a gentle U-shaped pattern, dropping until the late 1980s before rising through to 2007. The LFP of the young is rising through time, likely because of increasing participation by females. Finally, the unemployment rate of the young hits its highest points in the late 1970s and early 1980s when elderly LFP is at its lowest. This does not appear consistent with the crowd-out hypothesis.

We break this analysis down by sex in panels B and C of figure 12.1. The LFP of young males is fairly constant at around 80 percent over the entire span. Participation by elderly men rebounds only slightly in the late 1990s and does not reach the levels seen in the 1960s. In contrast, the LFP of both young and older women increases over the time period studied here. For younger women, the increase is concentrated in the first two decades of the sample up to the mid-1980s. In contrast, the LFP of the elderly women does not begin to rise until the mid-1990s, when it rises substantially. Finally, the cyclicality of male youth unemployment appears to exceed that of females.

Panel A of figure 12.2 displays the LFP of the elderly against the unemployment rate for the young and the prime-aged. The most noticeable pattern here is the cyclicality of the unemployment rate for the youth, which is mirrored in a muted way for the prime-aged. Panels B and C of figure 12.2 for males and females demonstrate again that males and younger individuals show more cyclicality. However, nowhere here is there any evidence of crowd out. When unemployment is at its highest in the early 1980s, elderly LFP is near its lowest.

Finally, panel A of figure 12.3 shows the employment rates of the youth 
A

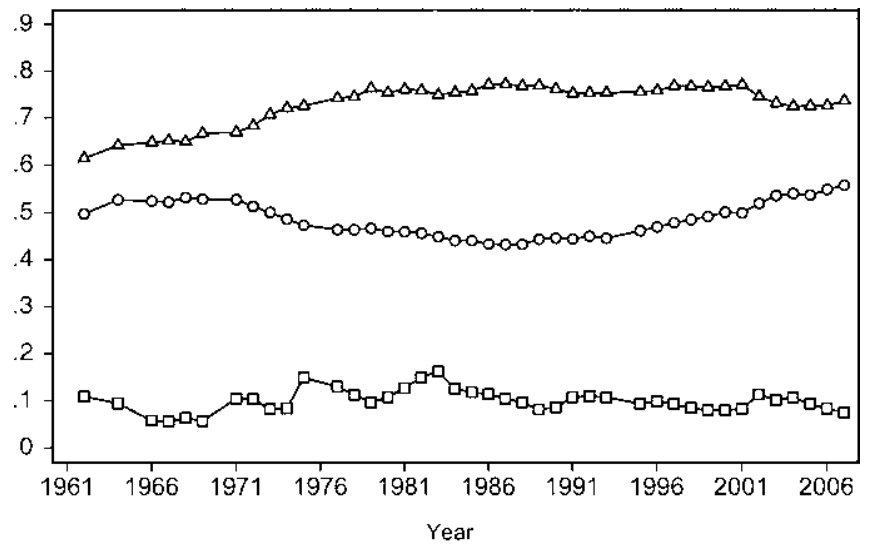

$\longrightarrow$ LFP of elderly
$\square-$ Unemployment rate of young

B

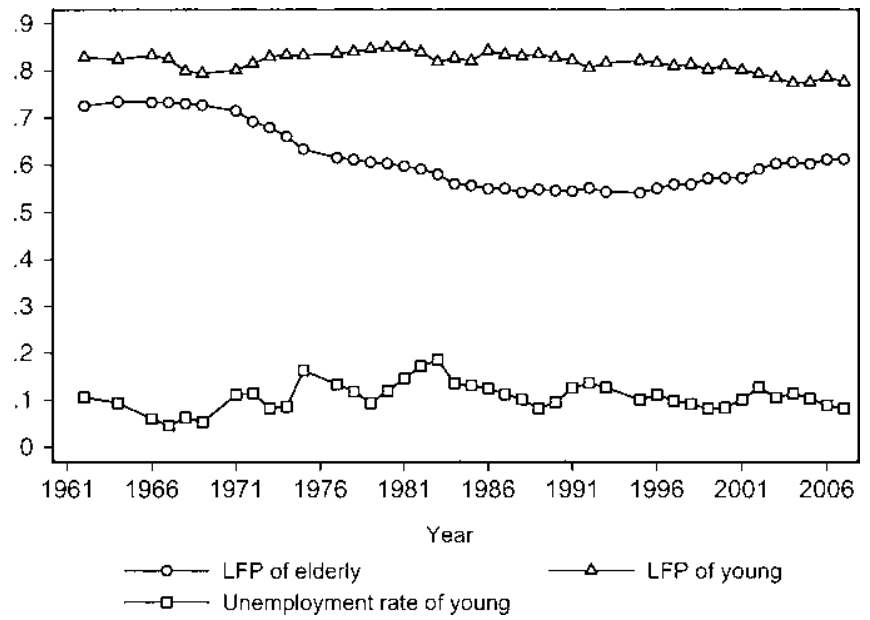

C

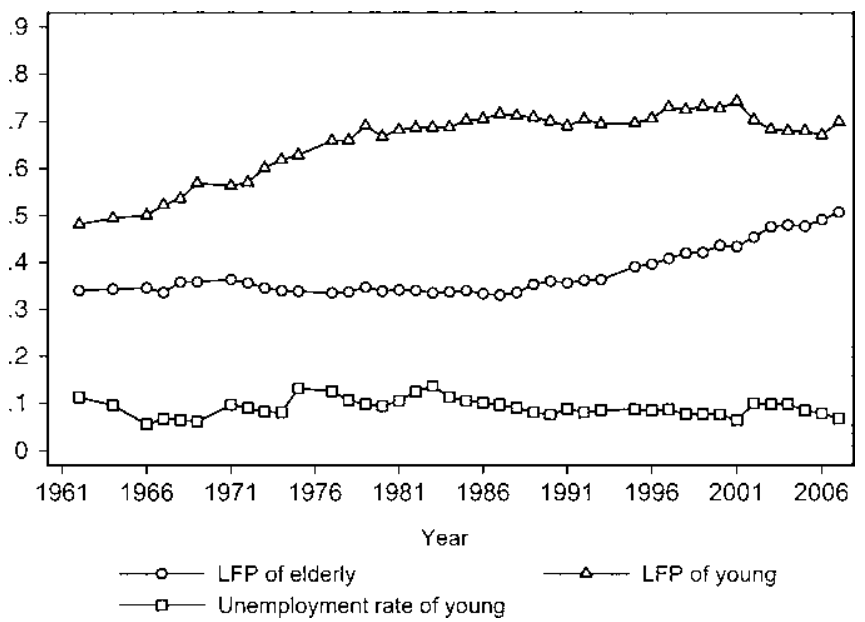

Fig. 12.1 Evolution of elderly labor force participation for elderly and the young: $A$, Both sexes; $B$, Males; $C$, Females 
A

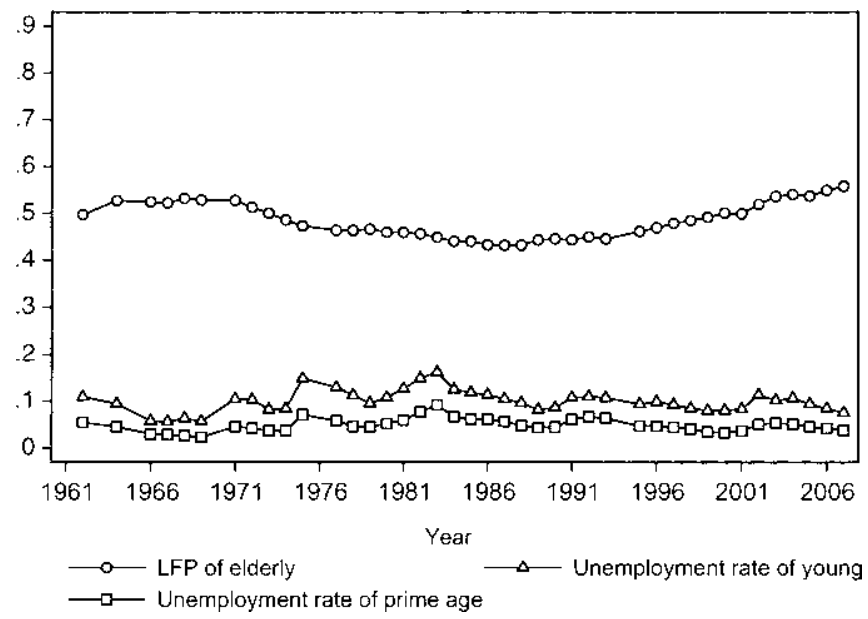

B

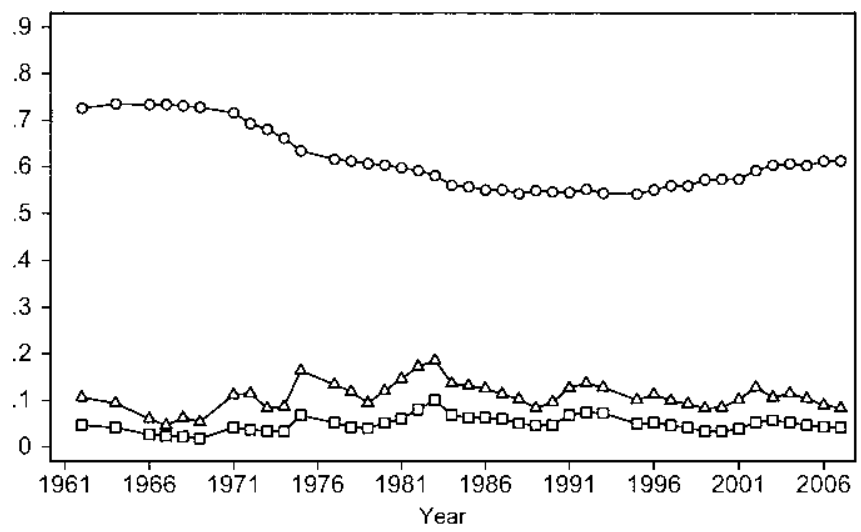

$\longrightarrow$ LFP of elderly $\longrightarrow$ Unemployment rate of young

$\longrightarrow-$ Unemployment rate of prime age

C

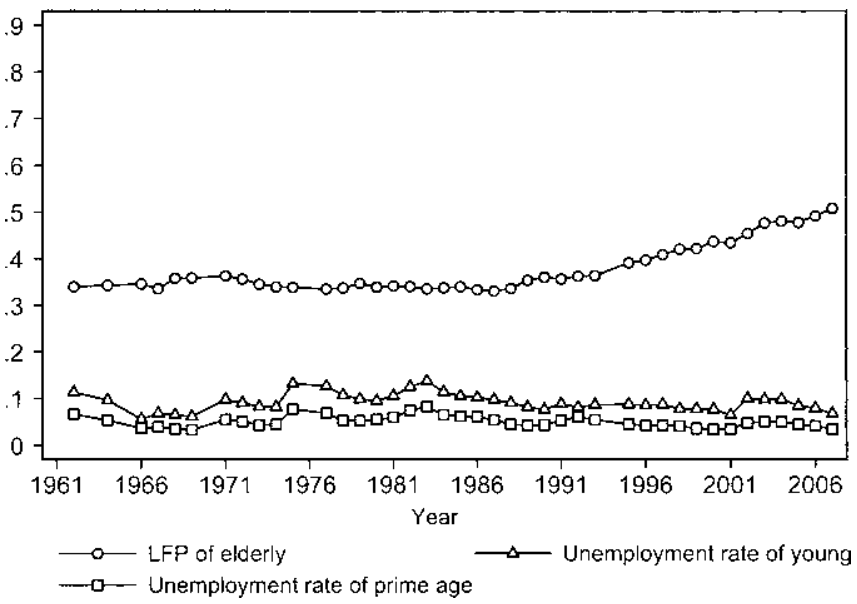

Fig. 12.2 Elderly labor force participation versus unemployment for the young and prime age: $A$, Both sexes; $B$, Males; $C$, Females 
A

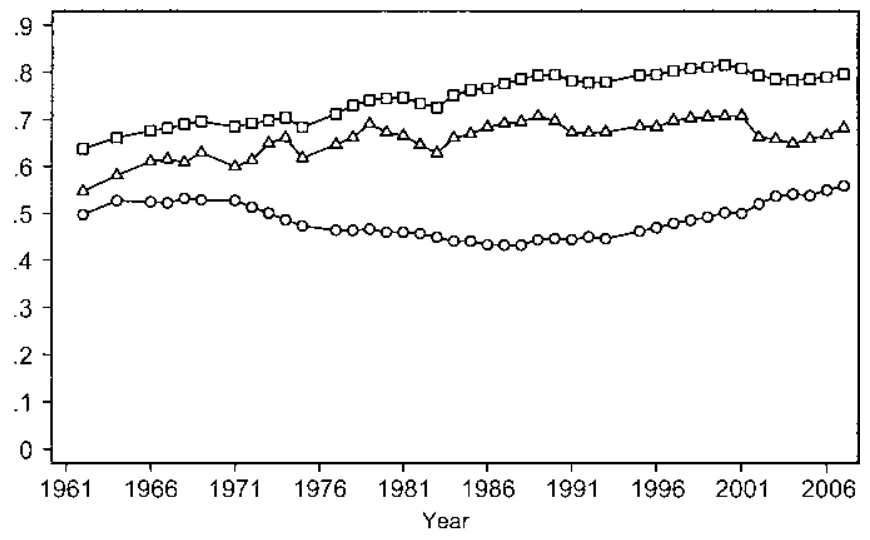

$\longrightarrow$ LFP of elderly

B

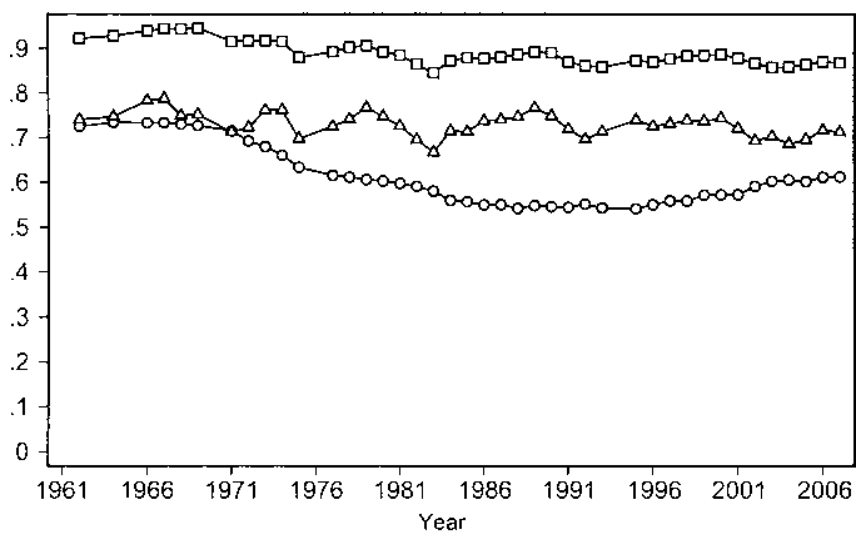

$\longrightarrow$ LFP of elderly
$\square-$ Employment rate of prime age

C

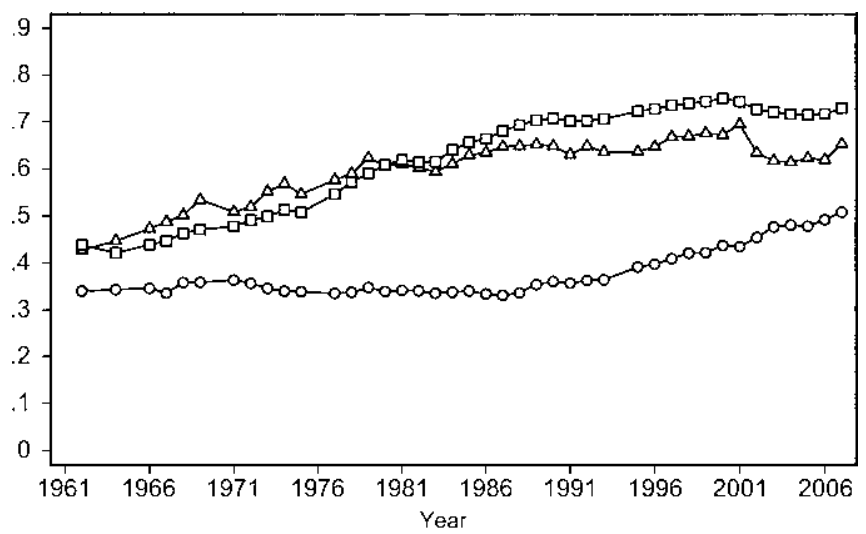

$\longrightarrow$ LFP of elderly
$-0-$ Employment rate of prime age

Fig. 12.3 Elderly labor force participation versus employment for the young and prime age: $A$, Both sexes; $B$, Males; $C$, Females 
and prime-aged against the LFP of the elderly. The employment rates trend upward over this time period. The breakdown by sex reveals in panel B of figure 12.3 that male employment rates do not trend (but are cyclical) and that there is a very strong upward trend for both youth and prime-aged female employment. Nowhere, however, is there sign of any crowd-out effect.

To summarize the graphical analysis, we find gentle U-shaped trends in the LFP of the elderly, but the labor market behavior of the youth and prime-aged is best described as cyclical for the males, and as following a secular upward trend for the females. The cyclicality and secular trend appear to be much stronger than any crowd-out effect.

\section{3 "Direct" Crowding-Out Regressions}

In this section, we formalize the graphical analysis of Section 12.2 by running time series regressions of the labor supply of the young and prime age on that of the elderly. We estimate time series regressions of the form:

$$
Y_{t}=\beta_{0}+\beta_{1} \text { ELDERLYEMP }_{t}+X_{t} \beta_{2}+e_{t} .
$$

For both the young and the prime age groups, we use unemployment rate and the employment rate as dependent variables $\left(Y_{t}\right)$. The key independent variable in each regression is the rate of elderly employment (ELDERLYEMP ${ }_{t}$. The additional control variables $\left(X_{t}\right)$ that we use in some specifications include the level of gross domestic product (GDP) per capita, and the growth rate of GDP per capita.

We employ four different specifications, in common with the other countries in this project. Each of these four is repeated first without any extra control variables and then with the extra $X_{t}$ control variables. For the first specification, we use the simple levels of elderly employment and the dependent variables. Next, we lag elderly employment by three years in order to try to avoid the impact of any contemporary shock affecting both sides of the equation. Third, we take the fifth difference of all the variables in the equation. Finally, we log both elderly employment and the dependent variable and take the five-year log difference.

Table 12.1 displays the results for men and women pooled together. Each cell reports the coefficient on elderly employment from a separate regression. Looking at unemployment rates in the first column, we expect an increase in elderly employment to increase youth unemployment if there is crowd out. However, the coefficients down the column are strongly negative. The -0.402 coefficient in the first row can be interpreted as follows: a 1 point increase in the elderly employment rate is predicted to decrease youth unemployment by 0.402 points. The coefficients, with one exception, are statistically significant. This evidence is against the crowd-out hypothesis.

The second column has the results for youth employment. Here, we expect a negative coefficient if elderly employment crowds out youth employment. 
Table 12.1

Direct regressions of labor market crowdout: both sexes

\begin{tabular}{lccccc}
\hline & \multicolumn{2}{c}{ Youth } & & \multicolumn{2}{c}{ Prime } \\
\cline { 2 - 3 } \cline { 5 - 6 } & UE & EMP & & UE & EMP \\
\hline \multirow{3}{*}{ Levels } & \multirow{2}{*}{ No controls } & & & \\
& -0.402 & -0.297 & & -0.258 & -0.136 \\
3-year lag on elderly employment & $(0.065)$ & $(0.174)$ & & $(0.040)$ & $(0.237)$ \\
& -0.224 & -0.507 & & -0.192 & -0.488 \\
5-year difference & $(0.097)$ & $(0.138)$ & & $(0.058)$ & $(0.221)$ \\
& -0.486 & -0.105 & & -0.337 & -0.110 \\
5-year log difference & $(0.127)$ & $(0.240)$ & & $(0.084)$ & $(0.157)$ \\
& -4.062 & -0.065 & & -5.189 & -0.078 \\
& $(1.025)$ & $(0.206)$ & & $(1.126)$ & $(0.118)$ \\
Levels & With controls & & & & \\
3-year lag on elderly employment & -0.415 & -0.468 & & -0.277 & -0.439 \\
& $(0.066)$ & $(0.098)$ & & $(0.038)$ & $(0.067)$ \\
5-year difference & -0.223 & -0.545 & & -0.195 & -0.558 \\
& $(0.098)$ & $(0.094)$ & & $(0.059)$ & $(0.055)$ \\
5-year log difference & -0.104 & -0.875 & & -0.065 & -0.539 \\
& $(0.119)$ & $(0.213)$ & & $(0.069)$ & $(0.162)$ \\
& -3.192 & -0.246 & & -3.991 & -0.163 \\
& $(1.137)$ & $(0.138)$ & & $(0.776)$ & $(0.088)$ \\
\hline
\end{tabular}

Notes: Reported in each cell is the coefficient on elderly employment in separate regressions with the dependent variable listed in the column headings. The standard error is beneath each estimate in parentheses. The different specifications appear in each row of the table. The specifications are explained in the main text. UE $=$ the share of the population unemployed; $\mathrm{EMP}=$ the share of the population in work.

Without controls in the top panel, three of four coefficients fail to attain statistical significance, but all are negative. In the bottom panel, with controls, all four coefficients are statistically significant at conventional levels, and all are negative. This suggests that more elderly employment leads to a decrease in youth employment, which is consistent with crowd out. Moreover, the coefficients are large. For example, with controls, the five-year difference specification yields a coefficient of -0.875 , which is the predicted drop in the youth employment rate with a 1 point increase in the elderly employment rate. This is somewhat confusing because the unemployment rate and the employment rate are moving in the same direction. This is possible, though, if there is a large increase in labor force exits. However, these estimates might be tainted by the secular trend increase in female employment through this period. We will check this further in the male-only results that follow.

The third and fourth columns of the table investigate the impact of elderly employment on the labor market behavior of the prime-aged twenty-five to fifty-four-year-olds. The same pattern emerges as for the youth-negative impacts for the unemployment rate and the employment rate across all specifications, with most attaining statistical significance. 
Table 12.2

Direct regressions of labor market crowdout: males only

\begin{tabular}{lccccc}
\hline & \multicolumn{2}{c}{ Youth } & & \multicolumn{2}{c}{ Prime } \\
\cline { 2 - 3 } \cline { 6 - 6 } & UE & EMP & & UE & EMP \\
\hline \multirow{2}{*}{ Levels } & No controls & & & \\
& -0.182 & 0.197 & & -0.141 & 0.369 \\
3-year lag on elderly employment & $(0.055)$ & $(0.058)$ & & $(0.031)$ & $(0.028)$ \\
& -0.024 & 0.070 & & -0.072 & 0.275 \\
5-year difference & $(0.073)$ & $(0.072)$ & & $(0.043)$ & $(0.044)$ \\
& -0.597 & 0.382 & & -0.400 & 0.417 \\
5-year log difference & $(0.151)$ & $(0.218)$ & & $(0.095)$ & $(0.101)$ \\
& -4.913 & 0.378 & & -6.214 & 0.328 \\
& $(1.327)$ & $(0.211)$ & & $(1.386)$ & $(0.081)$ \\
Levels & With controls & & & & \\
& -0.415 & 0.150 & & -0.277 & 0.323 \\
3-year lag on elderly employment & $(0.063)$ & $(0.088)$ & & $(0.035)$ & $(0.041)$ \\
& -0.260 & -0.051 & & -0.222 & 0.238 \\
5-year difference & $(0.101)$ & $(0.111)$ & & $(0.058)$ & $(0.069)$ \\
& -0.072 & -0.403 & & -0.054 & 0.009 \\
5-year log difference & $(0.143)$ & $(0.216)$ & $(0.085)$ & $(0.082)$ \\
& -3.498 & 0.157 & & -4.236 & 0.227 \\
& $(1.438)$ & $(0.206)$ & $(1.018)$ & $(0.055)$ \\
\hline
\end{tabular}

Note: See table 12.1 notes.

To check on the impact of the different trends experienced by males and females over this forty-five-year time period, we break out the results for males only in table 12.2. The results for the unemployment rates are the same in direction as was seen in table 12.1. The magnitudes are sometimes higher and sometimes lower, and statistical significance fails in some cases. However, for the males, the message is clear that the youth and the prime-aged unemployment rates drop when elderly employment increases. In contrast to the pooled sex results, the impact on youth is mixed and for prime-aged employment is strongly positive. For the youth, two positive estimates attain statistical significance at the 10 percent level, and there is one significant negative result. The rest are not statistically significant. For the prime-aged, seven of the eight are positive and statistically significant. The difference between these results and table 12.1 may be driven by the increasing female employment rates through time that contrast with the downward trend in elderly employment over this period. When just males are used, this effect is absent.

\subsection{Incentive Regressions}

In this section, we explore the use of an index capturing the incentive for elderly workers to retire. By using this index, we hope to use variation in the 
work behavior of the elderly that is related to policy changes rather than potentially endogenous economic shocks that might affect all parts of the economy. The index, described in more detail in the appendix, attempts to encapsulate in one number for each year in the data set the overall incentives faced on average by elderly labor market participants. This may be a somewhat difficult task to undertake because the time series variation in benefits is not large - as discussed earlier, the reforms of the system have been few, especially compared with many European countries.

A graph of the index values against elderly employment rates appears in figure 12.4. The Ibar line represents the full index, capturing both the wealth and dynamic incentive effects. The Wbar line shows the average value of Social Security Wealth among those still in the labor force. (Again, more details are in the appendix.) There are no sharp jumps in Wbar through time, so the growth in Wbar reflects wage growth across cohorts and through time. The sharp increase in Ibar after 1971 reflects the influence of the well-known "notch" in Social Security benefits. The impact of the notch lives on into the 1980s in this calculation because we average over the incentives faced by active labor market participants, and the "notch generation" was still active into the mid-1980s.

How should the index results be interpreted? When the index increases, it should decrease the labor force participation of the elderly. This means that we expect to see negative coefficients for the employment of the elderly when regressed on this measure. Following through, if there is less employment among the elderly, a positive coefficient among the youth or prime-aged would indicate that there is evidence of crowding out.

Table 12.3 begins the analysis, using the same eight specifications as in the direct analysis in tables 12.1 and 12.2. The top panel shows results without

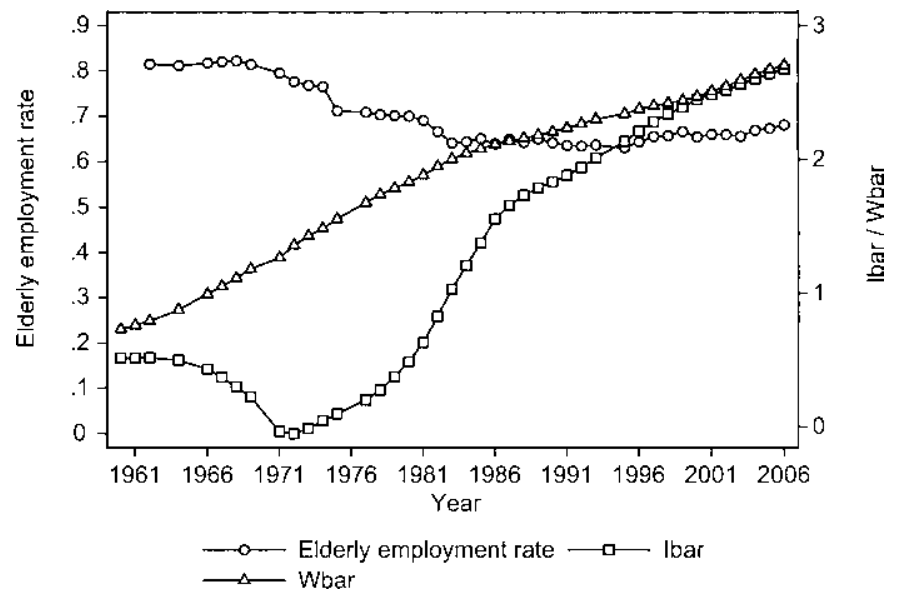

Fig. 12.4 Elderly employment rate, $\bar{I}(y)$ and $\bar{W}(y)$ 
Table 12.3

Impact of retirement incentives on the employment of the elderly, prime-aged, and young: both sexes

\begin{tabular}{|c|c|c|c|c|c|c|}
\hline & \multicolumn{2}{|c|}{ Elderly } & \multicolumn{2}{|c|}{ Youth } & \multicolumn{2}{|c|}{ Prime } \\
\hline & UE & EMP & UE & EMP & UE & EMP \\
\hline \multicolumn{7}{|c|}{ No controls } \\
\hline Levels & $\begin{array}{c}0.000 \\
(0.001)\end{array}$ & $\begin{array}{c}0.005 \\
(0.005)\end{array}$ & $\begin{array}{c}0.000 \\
(0.003)\end{array}$ & $\begin{array}{c}0.024 \\
(0.005)\end{array}$ & $\begin{array}{c}0.002 \\
(0.002)\end{array}$ & $\begin{array}{c}0.045 \\
(0.004)\end{array}$ \\
\hline $\begin{array}{l}\text { 3-year lag on elderly } \\
\text { employment }\end{array}$ & $\begin{array}{l}-0.001 \\
(0.001)\end{array}$ & $\begin{array}{c}0.015 \\
(0.006)\end{array}$ & $\begin{array}{l}-0.006 \\
(0.003)\end{array}$ & $\begin{array}{c}0.022 \\
(0.006)\end{array}$ & $\begin{array}{c}-0.001 \\
(0.002)\end{array}$ & $\begin{array}{c}0.043 \\
(0.005)\end{array}$ \\
\hline 5-year difference & $\begin{array}{c}0.000 \\
(0.004)\end{array}$ & $\begin{array}{c}-0.007 \\
(0.012)\end{array}$ & $\begin{array}{l}-0.016 \\
(0.010)\end{array}$ & $\begin{array}{l}-0.003 \\
(0.016)\end{array}$ & $\begin{array}{c}-0.002 \\
(0.007)\end{array}$ & $\begin{array}{c}0.013 \\
(0.010)\end{array}$ \\
\hline 5-year log difference & $\begin{array}{c}0.100 \\
(0.103)\end{array}$ & $\begin{array}{l}-0.025 \\
(0.010)\end{array}$ & $\begin{array}{c}0.047 \\
(0.071)\end{array}$ & $\begin{array}{l}-0.004 \\
(0.015)\end{array}$ & $\begin{array}{c}0.114 \\
(0.095)\end{array}$ & $\begin{array}{c}0.011 \\
(0.008)\end{array}$ \\
\hline \multicolumn{7}{|c|}{ With controls } \\
\hline Levels & $\begin{array}{c}0.005 \\
(0.003)\end{array}$ & $\begin{array}{l}-0.027 \\
(0.018)\end{array}$ & $\begin{array}{l}-0.005 \\
(0.010)\end{array}$ & $\begin{array}{c}0.004 \\
(0.014)\end{array}$ & $\begin{array}{l}0.008 \\
(0.006)\end{array}$ & $\begin{array}{c}0.026 \\
(0.010)\end{array}$ \\
\hline $\begin{array}{l}\text { 3-year lag on elderly } \\
\text { employment }\end{array}$ & $\begin{array}{c}0.000 \\
(0.003)\end{array}$ & $\begin{array}{c}0.029 \\
(0.018)\end{array}$ & $\begin{array}{l}-0.032 \\
(0.009)\end{array}$ & $\begin{array}{l}-0.012 \\
(0.014)\end{array}$ & $\begin{array}{l}-0.011 \\
(0.007)\end{array}$ & $\begin{array}{c}0.005 \\
(0.012)\end{array}$ \\
\hline 5-year difference & $\begin{array}{c}0.001 \\
(0.003)\end{array}$ & $\begin{array}{c}-0.009 \\
(0.010)\end{array}$ & $\begin{array}{l}-0.014 \\
(0.006)\end{array}$ & $\begin{array}{l}-0.004 \\
(0.015)\end{array}$ & $\begin{array}{c}0.001 \\
(0.004)\end{array}$ & $\begin{array}{c}0.014 \\
(0.010)\end{array}$ \\
\hline 5-year log difference & $\begin{array}{c}0.217 \\
(0.094)\end{array}$ & $\begin{array}{l}-0.064 \\
(0.015)\end{array}$ & $\begin{array}{c}0.069 \\
(0.087)\end{array}$ & $\begin{array}{c}0.015 \\
(0.017)\end{array}$ & $\begin{array}{c}0.191 \\
(0.092)\end{array}$ & $\begin{array}{c}0.025 \\
(0.010)\end{array}$ \\
\hline
\end{tabular}

Notes: Reported in each cell is the coefficient on the retirement incentive index in separate regressions with the dependent variable listed in the column headings. The standard error is beneath each estimate in parentheses. The different specifications appear in each row of the table. The specifications are explained in the main text. UE = the share of the population unemployed; EMP = the share of the population in work.

additional controls, and the bottom panel shows similar results from specifications with control variables. The first two columns contain the results for the impact of the index on the elderly. The results, mostly, are statistically insignificant. The five-year log difference specification does show statistical significance in the expected direction, with higher unemployment and lower employment indicated in years with higher values for the retirement incentive index.

A scatter plot of the fifth difference of the Ibar index and the elderly employment rate appears in figure 12.5. In this scatter plot, there is no clear relationship between the two variables. This may explain the lack of consistent findings in the first two columns of table 12.3.

For youth and prime-aged individuals, the results in table 12.3 are mixed. The youth columns show two statistically significant negative results for unemployment and two positive results for employment. If there were crowd out, this is the direction we would expect these coefficients to go. For the prime-aged, there is one positive coefficient for unemployment and several 


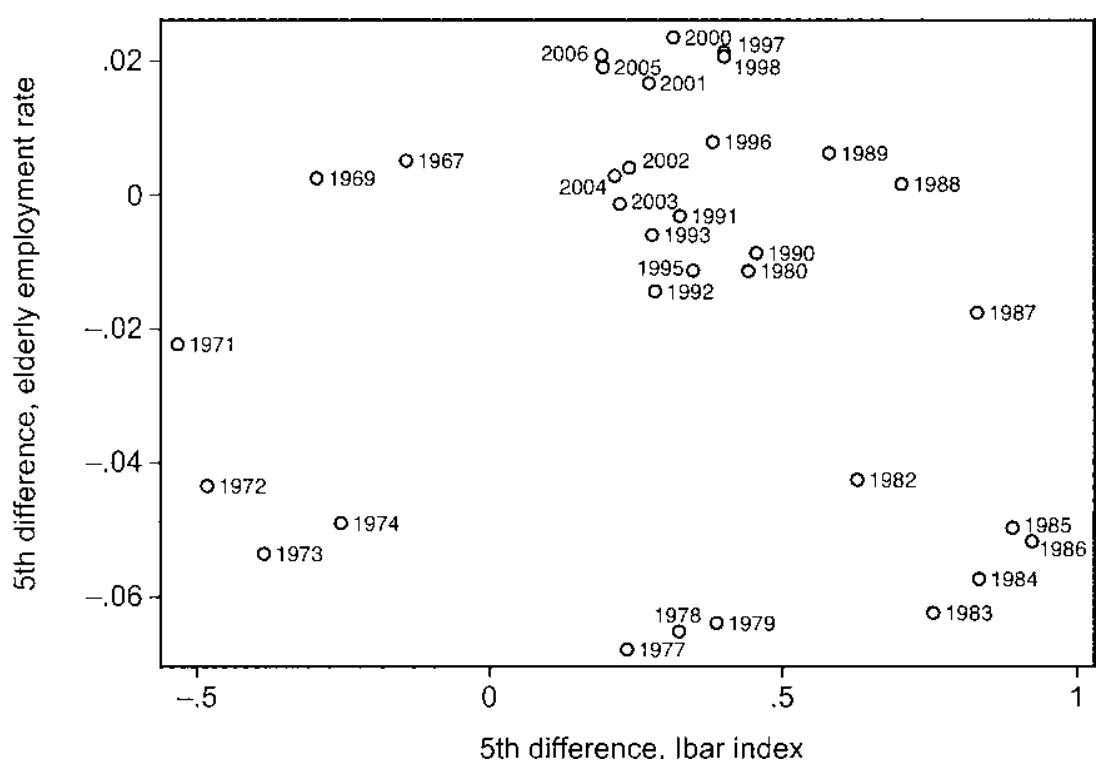

Fig. 12.5 Elderly employment rate and $\bar{I}(y)$ index in fifth differences

positive coefficients for employment. The stronger results for prime-aged employment are consistent with the idea of crowd out-higher retirement incentives for the elderly appear to be related to more employment by the prime-aged.

For these results, the caveat discussed earlier about the long-run upward trend of female employment again becomes important. For this reason, we again investigate the results just for men in table 12.4. In the first two columns for the elderly, the results are mildly stronger than the pooled men and women results, with several statistically significant findings. The positive relationship between the incentive index and unemployment - and the negative relationship of the index with employment - indicates that the incentive index is somewhat predictive of the labor market behavior of the elderly.

The results for the youth and the prime-aged, however, show no consistent pattern. There are a few statistically significant results across the table, but the signs are not clearly in one direction or the other. For example, the second row with the three-year lag on elderly employment shows a significant -0.015 drop for a one unit increase in the index. However, when controls are introduced in the sixth row of the table, the coefficient is now negative and significant at the 10 percent level. The overall impression of this table, however, is of no statistically significant relationship between the incentive index and the employment of young and prime-aged men. 
Table 12.4 Impact of retirement incentives on the employment of the elderly, prime-aged, and young: males only

\begin{tabular}{|c|c|c|c|c|c|c|}
\hline & \multicolumn{2}{|c|}{ Elderly } & \multicolumn{2}{|c|}{ Youth } & \multicolumn{2}{|c|}{ Prime } \\
\hline & UE & EMP & UE & EMP & UE & EMP \\
\hline \multicolumn{7}{|c|}{ No controls } \\
\hline Levels & $\begin{array}{l}-0.001 \\
(0.001)\end{array}$ & $\begin{array}{l}-0.048 \\
(0.007)\end{array}$ & $\begin{array}{l}-0.002 \\
(0.004)\end{array}$ & $\begin{array}{c}-0.010 \\
(0.004)\end{array}$ & $\begin{array}{c}0.002 \\
(0.003)\end{array}$ & $\begin{array}{r}-0.019 \\
(0.003)\end{array}$ \\
\hline $\begin{array}{l}\text { 3-year lag on elderly } \\
\text { employment }\end{array}$ & $\begin{array}{l}-0.002 \\
(0.001)\end{array}$ & $\begin{array}{l}-0.037 \\
(0.009)\end{array}$ & $\begin{array}{l}-0.010 \\
(0.004)\end{array}$ & $\begin{array}{c}-0.006 \\
(0.005)\end{array}$ & $\begin{array}{l}-0.002 \\
(0.003)\end{array}$ & $\begin{array}{c}-0.015 \\
(0.004)\end{array}$ \\
\hline 5-year difference & $\begin{array}{c}0.002 \\
(0.006)\end{array}$ & $\begin{array}{l}-0.008 \\
(0.014)\end{array}$ & $\begin{array}{l}-0.022 \\
(0.014)\end{array}$ & $\begin{array}{c}0.020 \\
(0.018)\end{array}$ & $\begin{array}{c}-0.002 \\
(0.010)\end{array}$ & $\begin{array}{c}0.007 \\
(0.010)\end{array}$ \\
\hline 5-year log difference & $\begin{array}{c}0.147 \\
(0.102)\end{array}$ & $\begin{array}{l}-0.028 \\
(0.009)\end{array}$ & $\begin{array}{c}0.057 \\
(0.088)\end{array}$ & $\begin{array}{c}-0.006 \\
(0.014)\end{array}$ & $\begin{array}{c}0.130 \\
(0.112)\end{array}$ & $\begin{array}{c}-0.005 \\
(0.006)\end{array}$ \\
\hline \multicolumn{7}{|c|}{ With controls } \\
\hline Levels & $\begin{array}{c}0.008 \\
(0.004)\end{array}$ & $\begin{array}{l}-0.041 \\
(0.023)\end{array}$ & $\begin{array}{l}-0.003 \\
(0.014)\end{array}$ & $\begin{array}{c}0.006 \\
(0.013)\end{array}$ & $\begin{array}{c}0.012 \\
(0.008)\end{array}$ & $\begin{array}{l}-0.008 \\
(0.010)\end{array}$ \\
\hline $\begin{array}{l}\text { 3-year lag on elderly } \\
\text { employment }\end{array}$ & $\begin{array}{c}0.001 \\
(0.005)\end{array}$ & $\begin{array}{c}0.033 \\
(0.025)\end{array}$ & $\begin{array}{c}-0.039 \\
(0.013)\end{array}$ & $\begin{array}{c}0.021 \\
(0.014)\end{array}$ & $\begin{array}{c}-0.012 \\
(0.009)\end{array}$ & $\begin{array}{c}0.019 \\
(0.010)\end{array}$ \\
\hline 5-year difference & $\begin{array}{c}0.004 \\
(0.004)\end{array}$ & $\begin{array}{l}-0.012 \\
(0.011)\end{array}$ & $\begin{array}{c}-0.017 \\
(0.008)\end{array}$ & $\begin{array}{c}0.015 \\
(0.014)\end{array}$ & $\begin{array}{c}0.004 \\
(0.005)\end{array}$ & $\begin{array}{c}0.003 \\
(0.005)\end{array}$ \\
\hline 5-year log difference & $\begin{array}{c}0.306 \\
(0.110)\end{array}$ & $\begin{array}{l}-0.061 \\
(0.016)\end{array}$ & $\begin{array}{c}0.087 \\
(0.098)\end{array}$ & $\begin{array}{c}0.015 \\
(0.021)\end{array}$ & $\begin{array}{c}0.264 \\
(0.099)\end{array}$ & $\begin{array}{l}-0.005 \\
(0.007)\end{array}$ \\
\hline
\end{tabular}

Note: See table 12.3 notes.

\subsection{Conclusions}

In this chapter, we have investigated the impact of elderly employment on the youth and prime-aged labor markets. In the "direct" regressions, we find some evidence that movements in elderly employment are negatively related to prime-aged employment. However, our males-only evidence suggests that these findings may be tainted by the inclusion of women, who experienced a large secular increase in employment over this period. Using the incentive index, we find little evidence of crowd out. But our incentive index is not strongly predictive of the labor market behavior of the elderly, so this may reflect more on the difficulty of exploiting the available policy variation in a time series study.

Our conclusion, therefore, is relatively weak. We find no consistent evidence of an impact of the employment of the elderly on the young or prime-aged in our sample. This evidence for one country alone may not be conclusive. However, when placed in the context of the other countries in this project, it is possible that stronger conclusions may be drawn-again highlighting the potential power of the multicountry analysis. 


\section{Appendix}

\section{Incentive Index Construction}

Please note that this discussion is drawn from the Canadian chapter because the construction of the index followed very similar methodology and computer programs.

The goal of the exercise is to arrive at a single incentive number for each calendar year to be used in the time series regressions. We begin with a profile of median earnings for a central cohort. This earnings profile is then shifted for inflation forward and backward to generate equivalent real wage profiles for all birth cohorts. This method ensures that the only difference in incentive measures across years will be in changes in benefit formulas and not cross-cohort differences in wages.

These cohort age-earnings profiles are next pushed through a detailed calculator for Social Security benefits. At each age from fifty-five to sixtynine, we calculate the capitalized value of future benefits (Social Security Wealth, or SSW) and also the "peak value" concept found in Coile and Gruber $(2004,2007)$. The peak value represents the difference between current SSW and its highest value in the future, given current information for a forward-looking individual.

To collapse this down to an annual time series, we start by recognizing that an individual viewed at age $a$ has faced retirement incentives at age $a, a-1$, $a-2, \ldots$ back to the first age of eligibility. We, therefore, average the incentives within a cohort across ages (from the current age back to age fifty-five), using the aggregate age-year-sex specific labor force participation as weights. We generate the age-year-sex labor force participation rates from the CPS. Because this survey only goes back to 1962 and is also missing some years, we fill in missing years and extrapolate backward using an assumption of constant age-sex labor force participation rates. This calculation gives us an average exposure to retirement incentives for each cohort in each year of interest.

The final step involves collapsing the average incentive measures to a single number for each year. This means we must average the incentive measures faced by each cohort in a given year. To do this, we weight by the proportion of the population represented by each age in a given year.

To enrich the measurement of incentives, we assign a weight to the SSW component and the peak value component. We determined these weights using an iterative technique, finding weights that maximized the fit of a regression of elderly LFP on the incentive measure.

The foregoing can be expressed mathematically as follows. The incentive measure $I$ at age $a$ and year $y$ can be expressed as:

$$
I(a, y)=\left\{\gamma W(a, y)+\alpha\left[W(a, y)-\mathrm{PV}^{*}(a, y)\right]\right\},
$$


where $W(a, y)$ is the SSW at age $a$ and year $y, \mathrm{PV}^{*}(a, y)$ is the peak value of SSW, and $\alpha$ and $\gamma$ are the weighting parameters for the wealth level and peak value difference, respectively. These $I(a, y)$ terms are then summed across all previous ages, within cohort:

$$
\bar{I}(a, y)=\sum_{a=55}^{a=69}\left(\left\{P(a, y) \times\left[\frac{\sum_{t=0}^{a-55} I(a, y) \cdot \operatorname{LFP}(a-t, y-t-1)}{\sum_{t=0}^{a-55} \operatorname{LFP}(a-t, y-t-1)}\right]\right\} / \sum_{a=55}^{a=69} P(a, y)\right),
$$

where $\operatorname{LFP}(a-t, y-t-1)$ is the labor force participation rate for a member of the cohort in a previous year. The extra minus 1 accounts for the fact that we want the labor force participation rate at the beginning of the year, not during the year. Finally, we average across all cohorts in a particular year, where $P(a, y)$ is the population of the cohort in a given year. This $\bar{I}(y)$ term is the incentives index used for the regressions appearing in tables 12.3 and 12.4 .

We also make use of $\bar{W}(y)$, which is calculated by substituting the SSW of the individual at age $a$ and year $y, W(a, y)$, in for $I(a, y)$. This $\bar{W}(y)$ term calculates the average pension wealth across individuals in a given year.

\section{References}

Coile, Courtney, and Jonathan Gruber. 2004. The effect of Social Security on retirement in the United States. In Social Security programs and retirement around the world: Micro-estimation. ed. Jonathan Gruber and David A. Wise, 691-730. Chicago: University of Chicago Press.

2007. Future social security entitlements and the retirement decision. Review of Economics and Statistics 89 (2): 234 46.

Committee on Ways and Means. 1998. Bunning announces eighth hearing in series on "The future of Social Security for this generation and the next," Committee on Ways and Means, Subcommittee on Social Security, Advisory no. SS-13, February 13, 1998.

Diamond, Peter, and Jonathan Gruber. 1998. Social Security and retirement in the United States. In Social security and retirement around the world, ed. Jonathan Gruber and David A. Wise, 437-73. Chicago: University of Chicago Press.

Hicks, Nancy. 1977. Retirement-Giving it five more years-Who wins, who loses? Black Enterprise 8 (5): 33.

Smith, Erika. 2003. Senior citizens are among teenagers' job competition. Akron Beacon Journal, May 12, 2003. 